\title{
An Analytical Study On Socio-Economic Conditions Of Squatter Settlements In Karachi
}

\author{
Aamir Waheed Khawaja \\ Department of Social Work \\ University of Karachi \\ Nasreen Aslam Shah \\ Department of Social Work \& Women's Studies \\ University of Karachi
}

\begin{abstract}
This research study was conducted on socio-economic conditions of families living in squatter's settlement of Karachi. The urban population is booming with unprecedented growth due to heavy influx or migration of rural population to the cities especially in Karachi. The rural families are migrating to the city in a way to have better employment; improved lifestyles in urban societies. Migrators usually accommodated in squatters' settlements of Karachi because of high residing cost in urban areas. The squatters' settlements are located at outskirt of the city on government owned lands. However the provincial government has set up Sindh Katchi Abadi Authority (SKAA) department for upgrading or regularizing Katchi Abadis which are working under specific rules and regulations. In this study the role of SKAA also highlighted to analyze the working preferences of organization for the rehabilitation or betterment of squatter settlements. The research topic is chosen in order to investigate about the socio-economic issues of families living in squatters settlements. The data is collected from 200 respondents of squatters from squatters' settlements which are situated in six different districts of Karachi. Data is collected by the self-prepared questionnaire which was prepared in a way to investigate socio-economic issues and problems of squatters' families living in the settlements. This research found that whole sample of squatters is of migrators. These settlements are considered illegal and have no provision of basic necessities including drinking safe water; inadequate sanitation system; and low standard of housings.
\end{abstract}

Keywords: Squatter Settlements, Poverty.
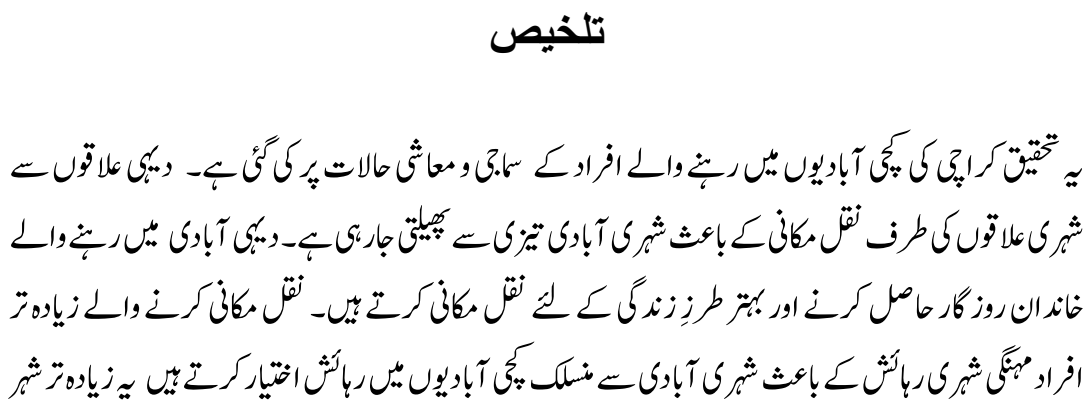


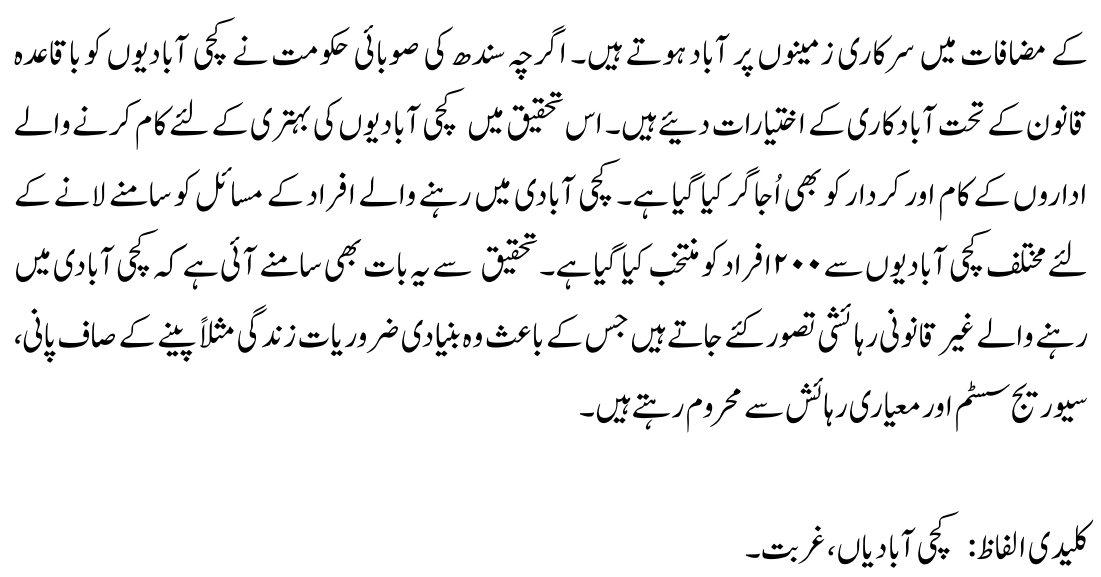

\section{Introduction}

From the mid of $19^{\text {th }}$ century, globalization has primarily expanded economic zones however, social and cultural aspects are also integrated and it has massive influence on every individual around the world. Similarly, urbanization is also a by product of globalization because due to enhanced economic activities in urban areas, people are migrating from rural to urban in order to get involved in mainstream economics activities to get facilitated through employment opportunities (Durrschmidt, 2013). The shift of rural population to urban cities have increased at faster pace, which resulted in many negative and positive factors. According to the United Nations (2014) it is envisaged that 66 percent of world's population likely to be lived in urban areas by 2050. The phenomenon of urbanization has borne slum areas and squatter settlements; it is due to bad governance by the government and authorities (United Nations, 2014).

About 900 million people around the world are living in squatters, which almost constitutes ten percent of total world's population, United Nations reported in 2005. Usually rural migrants have come to cities in search of jobs and started living in outskirts of cities. It is fact, people occupy empty areas and vacant building without owner's consent which is illegal but it happens due to unaffordability of rent houses or do not have sufficient finance to bear legal housing in urban areas (Perlman, 2010). It is estimated that in South Asia around 58 percent of population living in squatters and slum areas (Ooi \& Phua, 2007). According to researches on squatters settlements there are few cases discussed such as India's 60 percent of population living in slums areas; about 50 percent population in Turkey and 20 percent population in Brazil (United Nations, 2010).

In South Asia, around 191 million people living in squatter settlements and slums because people from rural economies are moving with faster pace in order to get better employments and basic necessities. Most of the regions of South Asia have densely populated urban areas with having squatters at outskirts of the cities. The 
poverty always pushed migrants to become squatter as they are facing extreme poverty because Bangladesh at 71 percent; Nepal at 59 percent and India at 32 percent where there maximum population living in slums and squatters settlements (ADB, 2012).

Moreover, according to available literatures, it is very unusual that in United Kingdom and United States' people are self-reliant while acquire housing. It is observed that the third world countries that there are departments working for squatters for rehabilitation of people living in slums and squatters through regularizing approach or under different housing schemes (The Guardian, 2012). However, in United States phenomenon of squatting is revolving around the political aspects where poor or homeless are working or supporters of the class who owned wealth in the state. Whereas; in third world countries the situation is differing from the first world because classes are struggling for acquiring lands. There are very few unoccupied housing units and in fact, they have high rents which are unaffordable for rural migrants (Fisher, 2012). Due to the reason, urban squatters usually occupy vacant places or construct their own residing places on short term and long term basis. Rural migrants usually rely on agricultural employment because of the reason people reached to urban areas get involve in cheap labour with lower wages. Due to the reason, in start the land squatted by two or three and then occupies thousands of acres land illegally with poor provision of basic facilities (Satterthwaite \& Hardoy, 2014). They have been called as second-class citizens where they hardly grow or cannot further exploit economic activities. According to Haque (2012), squatters have evolved their own paradigm where they do not trust on state and private sector of the country however, striving hard for betterment of their lives (Haque, 2012).

Nenova (2010) stated that Pakistan is facing the similar conditions; as discussed above in other countries squatters and slums, according to available records about more than half of its population living in squatters. Squatters usually belong to lower-income groups; having illegal habitats and temporary jobs usually part time. Karachi is a city of lights being titled as the 'Planet of Slums' by Devis (2006); where more than half of population living in urban squatters which are usually called as 'Katchi Abadi' or slums (Amrith, 2011). In Karachi, according to official statistics there are 702 'Katchi Abadis' (Pervaiz et, al. 2008). The people living in 'Kachi Abadi' have fewer resources in a way to make living in metropolis of Karachi. Most of the times their savings spent on housing and in other utilities and they are remain unsound in attaining growth, as migrants always come up with an hope to upgrade their lifestyle and smooth deliverance of basic necessities of life. 


\section{Squatter Settlement}

The term squatters is defined as a person who occupies vacant place or property with no legal documents is called as squatter. However, he/she has no right to lease that place. All the time it is observed that squatters inhabited at places especially where property owner do not visited the place for many years. Though he/she is the real owner and takes possession anytime for using the land. The legal and real claimants are always those who owned papers and other legal documents, Birkmann (2006). Abrams (1964) defines squatters in two types; first, squatter who does not inhabited in long term possessions however they are usually street sleepers and most of the time they are being called as mobile squatter which are common in First World Countries. Second, squatters defined as who occupy place with no legal papers and build houses on it, which is common among developing nations (Abrams cited in Basu, 1988).

\section{Objectives of the Study}

The objectives have been framed in order to identify the outcomes of this research study which are as follows:

1. To find out the specific pattern of the families living in squatters settlements.

2. To discover the specific economic activities and sources of income of the family.

3. To explore the income of the family.

4. To find out the occupational patterns of the family.

\section{Research Question}

This research comprises of two research question which are as under:

1. The first research question of the study is "Migrant families desirably wanted to live in squatter settlements."

2. The second research question of the research is "People having petty occupations and artisans live in squatter settlements."

\section{Literature Review}

Urbanization increasing to many folds in all over the world. According to available records about half of the world's population living in urban areas (United Nations, 2014). Ushakov (2015) believed that people living in cities are more socially developed and civilized which brings ultimate prosperity in everyone's lives. However, it is also observed that migrants had to go through years or decades of hardships in a way to materialize their actual purpose of migration to cities (Jansson, 2007). In fact, about 82 percent of North American population living in cities which considers highest in the world (Setoet, al. 2016). 
Similarly in Asian countries around 40 to 48 percent of population living in urban areas (McGee et al., 1991). Whereas, Pakistan's urban population have been increasing annually by 2.8 percent (National Research Council, 2012). According to sixth census of 2017, total Pakistan's population of urban cities has reached to 36.38 percent (Tariq, 2017) and further added that it will reach to 50 percent by 2025 (UNESCO, 2010). According to the World Bank, since 1990 urban locales would have increased to three folds in Pakistan. It is also mentioned that the data of changing population never be calculated by the authorized officials. Rural migrants are often living under squatters' settlements with limited opportunities and with inadequate living standards (UN-Habitat, 2000).

It is observed that multi-facets problems are rising due to lack of planning about rural to urban migrations. However, rural population migrates for better future prospects and mainly for economic opportunities (Denis, 2014). Whereas, the existing scenario is quite different because urbanization process is very slow (Dr $\mathrm{Yu}, 2014)$. All the new migrants have to live in squatters and slums which are crowded, unhygienic and with extreme poverty. At that time people are jobless and homeless; they do not even have basic necessities such as safe water, proper sanitations system and proper food (Ushakov, 2015). Though the reason of influx was 'To have provisions of all basic needs including education, health care, clean areas, and civilized societies and so on' of course by exploiting good income jobs in the cities (Yumin \& LeGates, 2014). For this reason the government has done very little as this migration process is still undocumented and living as illegal occupant on the squatted lands. It is unveiled that there are no future plans for settling such squatters living under bad conditions. It is estimated that around 50 percent of squatters living illegally at government owned lands in Karachi, which is still among high as compared to other settlements in the world (Anjum, 2011).

IMF (2006) reported that poor who are living under the poverty involves in crimes. Their wellbeing and social development have been hindering due to intolerable risk factors and no social safety in the city. These constraints pushing migrants to rely on informal sector of the economy while finding job, or learning new skill, exploring support for housing. In fact, rural influx cut the expenses on health services, spending on occupied places while fulfilling needs of food for the family. Many scientists believed that urban slums are major drivers of poverty including malnutrition and poor health which is considering even better, as were living or spending life in the 'rural poverty'. According to Akhter Hameed Khan Resource Centre (AHKRC, 2016) research, the government was mapping urban slum areas of Rawalpindi for provisioning of basic services, they had allocated services for about 70, 000 squatters while mapping area whereas the actual population was 195,000 and these figures were created demand of services for about $2 / 3^{\text {rd }}$ of the squatters of that area. According to census report of 1998 Pakistan urban population was about 35 percent, which has increased to 300 percent in 2015. It can depict that 
government has no accurate available data of squatters' settlements in a way to deliver basic services to squatters of the country. The existing situation will never be changed if concrete steps not taken timely by the government.

For urban growth there have been many constructive researches and concrete work done in developed nations to develop parallel planning for its up-gradation of slums and squatters' settlements (United Nations, 2005). Whereas developing nations have different attitudes towards growth of urban cities such as in China, India and Pakistan, that authoritative bodies do not evolved strategic planning's to overcome with the socio-economic issues of squatters' in countries. These states should minimize the information gaps in order to utilize rural population in some specific tasks according to human capital, skills, to engage them economic activities in the country. The process of urbanization should be made compatible for rural migrants through acknowledging diversity in cultures and economics. It is recommended by the AHKRC (2016) that urban employment market can generate multiple jobs by recognizing migrants' efficiency of work, specializations, and patterns of work.

According to UN Habitat report of 2011, Karachi will become a mega city of over 10 million urban population by 2020. There are other nine cities that will have combined population of over one million by 2020 including Faisalabad; Gujranwala; Hyderabad; Islamabad; Lahore; Multan; Peshawar; Quetta and Rawalpindi. Karachi and Lahore are considered the densely populated cities facing economic hardship in order to provide jobs to unemployed squatters or migrants despite large-scale manufacturing industries.

Rural influx to urban will increase to 250 million populations by 2030 in South Asia including Pakistan (Umar \& Indo, 2017).If taken guide from history so, movement of rural masses to urban cities expanded the economic activities in the regions as a whole. It is observed that urbanization can also transform economies through engaging migrants into formal economy by creating employment in production, manufacturing and services sectors (Wood, 2010). It will increase the total gross domestic group (GDP) of the country which could lead toward achieving desired economic growth and also impactful on dwellers through better living standards of migrants who are living in vulnerable conditions at squatters' settlements.

\section{Socio-Economic Problems of Squatters Settlements}

Usually developing countries have less capacity to absorb influx of population to urban areas (Maheshwari et al., 2014). Due to the reason informal settlements create jobs for squatters or migrants and even housing at outskirts of cities which is accounted as informal sector of the economy (Gukuruma, 2012). It is observed that progress in improved living structures of informal settlements is very limited because these groups belong to lower-income. These poor conditions are 
depicting the bad governance by the country. Squatters' settlements in all the developing countries are overcrowded; which are highly populated with number of housings on small lands and number of family members' living in a single unit (Haque, 2012). Because of the crowded settlements they have the most poor sanitation system in dwellings as their excreta often found outside the houses (Thompson, 2002). The research conducted in 2008 on employments structures of India squatters' settlements to over 109 dwellers by both the genders who are engaged in small occupations working as "Kabadi; sweeper; municipality; factory workers; domestic maids; cycle repair; driver; Tailor rickshaw puller; petty business; barber and cobbler." However, the income patterns are very low to manage day-to-day expenses. The dwellers earnings are falling between 1000 rupees to more than 3000 rupees on monthly basis (Ghosh, 2008).

In developing countries access to health services would have positive impacts on poor population of the country. In fact poor households spent little over healthcare but they often have poor quality access. It is witnessed that substandard housing creates many chronic diseases and infections into people living in crowded land areas. The diseases are included: hypertension; diabetes; tuberculosis; aids; heart diseases; cholera; malaria which required immediate treatments to overcome the disease, however early diagnose of any viral and illness would help to cure patient from going into more crucial stages. And all such diseases get treated at formal hospitals rather in clinics of the areas. There are public sector hospitals who are working free of cost but have long queues to get appointments however, medicines will have to purchase by the patient himself or herself. In Karachi slums, the mortality rate of children have been recorded about 92 to 152 per thousand live births whereas, 32 per thousand in middle class areas (Ruskulis and Schilderman, 2005).

According to the UN Habitat report 2015-2016 observed the highest prevalence of slums in Southern and Western Asia, where the literacy ratio is very low among dwellers of slums. As per recorded figures of global illiteracy ratio, about more than 52 percent of population of Southern and Western Asia has no education. Whereas Sub-Saharan Africa adults adding about 22 percent; around 13 percent in East Asia and the Pacific. However, Arab states constituting 6.5 percent and 4.7 percent by Latin America and the Caribbean, in global illiteracy rate (UNESCO, 2012). UNESCO report said that urban areas have larger number of youth population which is growing at faster pace. It is also recommended that investments in education and skills for youth would have positive impacts on dwellers livelihoods and also on economic growth. It is also calculated that investing one dollar on education would yield ten dollars to 15 dollars while achieving economic growth of the country for the lifetime of a person. In Pakistan's total population about 50 percent of people are under the age of 25 who are young and have energy to work hard. Substandard or even no education is the hindering factor in development of youth as a whole (Buhne, 2016). 


\section{Roles of Sindh Katchi Abadi Authority (SKAA)}

Sindh Katchi Abadi's Authority (SKAA) had initiated in 1987, there were many amendments made to the act gradually, for regularization of the Katchi Abadi of Sindh. Within five years of SKAA establishment their policies for leasing house was very difficult. It had 25 steps to go through procedures in which squatters had to visit different offices of SKAA and usually left the leasing procedure incomplete (ADB, 2008). In fact, dwellers were daily wage earners they did not always available to reach the office daily. So, these rigid procedures discourage squatters, whereas fostered the corruption process where a squatter can apply for lease by giving bribery or kickback ways (Wehrmann, 2008). The bribery was ranging between 400 rupees to 1200 rupees, which was considered a huge amount for poor to pay for speedy clearance of lease (UNDP, 2002). However, it is also come to knowledge that squatters even did not know the actual fix fee of leasing. It ultimately concludes that regularization process was never being transparent.

It is pertinent to mention that in 1990's the mode of development they had chosen was reflection of British and American standards, in addition it included over designing of houses which ultimately increased the cost of lease and were unaffordable by the dwellers of Katchi Abadi (UNDP, 2002). However, directorates of SKAA would planned according to available resources and could built regular housing for permanent shelter by using good cemented materials rather focusing on its designing. For that purpose the authority hired engineer contractors and consultants which increased the cost by 100 percent (Ismail, 2004). The cost was being paid by the dwellers living in slums, whereas as per observations 30 percent bribery was taken from dwellers during that time in order to faster the process of construction and leasing. In fact, authority had no budgetary allocations for housing development but the process was being run by using limited funds received by the donor agencies and from local government (Yusuf, 2005). Eventually, most of development work did not reach to its completion and because of slow pace dwellers were discouraged and also reluctant to lease the squatters' settlements.

Due to the set-back, new directorate had been brought to Sindh Katchi Abadi Authority (SKAA) for the development of easing policies for squatters' settlements. Then they had primarily conducted socio-economic surveys of squatters' settlements where they had been located exactly and their surveys included purpose of land used; proof of occupying place; and probe about councilor certificates (Ahmed, n.d.) Their surveys found and notified that the number of squatters' settlements which were built by previous authorities being reported as of sub-standard. It was being reported that Katchi Abadi's were built by engineers who had quoted more rates for this work in tenders; and the work was of extreme poor quality and did not examined the construction work by SKAA at that time. They built poor quality houses where the land was degraded and hazardous for housings. 
However, SKAA had brought with new approach where they setup mobile leased camps at Katchi Abadi's in order to regularize squatters' settlements by itself. The authority had designed proper procedures for leasing the squatters. SKAA had accepted applications and affidavits of squatters who were willing to get lease and in fact, all specimen had been filled by their own office staff (Hasan, 2012). In addition with these legal procedures, SKAA officials had interactions with squatters in order to brought them under confidence; nominated nearer bank branches for deposit of money for leasing purpose; assist squatters in getting liaison with sub-registrar; and SKAA publicize their lease camps through various means such as hoardings; banners and posters while SKAA officials were also available for providing information at any mobile office which were setup in every Katchi Abadi's.

According to available data, around thirty files were prepared and sent to process in a single day by two member team constituted at every Katchi Abadi (UNDP, 2002). SKAA clearly mentioned by highlighting previous unscrupulous experiences that this new approach laid down clear cut policies of cut-off dates which would increase the pace of procedures. It was also significant that squatters who were falling under category of lease but reluctant to approach authority might be due to lack of knowledge or fearing about long procedures of months and years. Whereas, to remove such doubts their camps were opened for fix period of two month in order to attract number of squatters in short period of time. Though there was no expiry of date for leasing as interested squatters could contact SKAA officials directly in their office. They further facilitated the poor squatters in such a way, if squatters cannot afford the lease amount could be paid in instatements (Dr Ahmed, 2016). This research study is also observing the changes after and before SKAA establishments as are they just tall claims, or have worked for the betterment of the squatter settlements and slums specifically in Karachi.

\section{Development Work by SKAA from 2009 to 2017}

The government has allocated annual development budget for the development of Katchi Abadi's in Sindh. It has been observed that allocation of budget decreasing and shrinking over the time, whereas the population of Katchi Abadis'increasing. In fact, the government releases less as per allocated amounts by the federal budget. Though it is also admitted by the Deputy Chief organizer Katchi Abadi and Goth Federation of Pakistan Muhammad Shoaib Khan; that no budget had been allocated for Sindh Katchi Abadis' and villages, however they given 40 percent votes in election (Maqsood, 2016). According to available data, in 2009 to 2010 government had released 100 million rupees funds which were utilized in work of construction and development. Likewise, in 2010-2011; government released 100 million rupees, in 2011-2012; government released 110 million rupees, in 2013-2014; government allocated 121 million rupees, however only 30.250 million rupees were released, in 2014-2015; government allocated 87.120 million rupees, however only 30 million rupees were released, in 2015-2016; government released 57.120 million 
rupees, and in 2016-2017; government releases 44 million rupees for the construction of housing and development of Katchi Abadis' in urban located areas. The authority utilized the funds by covering following development projects for last six years including: four roads; three water supply systems; 22 sewerage line; two electricity grids; and six CC topping and CC drain systems in Karachi. Similarly, in Hyderabad seven roads constructed; six sewerage line; two electric grids; and seven $\mathrm{CC}$ topping and $\mathrm{CC}$ drain. In Mirpurkhas only five $\mathrm{CC}$ toping and $\mathrm{CC}$ drain were built in whole development process. Whereas, in Sukkur lot of work done including four roads construction; four sewerage lines; two electric grids; and four CC toping and $\mathrm{CC}$ drain. In Larkana, there is few development works have been done including two roads; five sewerage lines; and four $\mathrm{CC}$ topping and $\mathrm{CC}$ drain. In Shaheed Benazirabad, only three CC topping and $\mathrm{CC}$ drains were constructed in whole development process, information collected from SKAA department.

In October, 2017, SKAA has regularized five Katchi Abadis' which are located in Karachi. It is included: Shanti Nagar; Awami Zamrud Colony; Quaid-e-Azam Colony; Mustafa Colony and Kando Goth. There are about 5000 housing units which were squatting in these areas since 1985 and now the squatters got the possession rights of the land. Moreover, construction of roads and streets in area Bedal town and Awami Zamrud colony have been started and further provision of basic necessities to be given in the area (The Express Tribune, 2017). SKAA further planned 15 other slums of Karachi to be regularized in next the term.

\section{Methodology}

The groups of squatters' settlements have been chosen from the list provided by the Sindh Katchi Abadi Authority (SKAA) of regularized and non-regularized Katchi Abadi's in Karachi. The list has total 564 Katchi Abadis; from which around 200 respondents have been selected from five districts of Karachi and this study is using convenient sampling method for collecting data of squatters. For this research, self-preparatory questionnaire was designed in which it contains 19 open ended questions and 72 close ended questions.

\section{Districts of Karachi}

\begin{tabular}{|l|c|}
\hline Districts & Sample \\
\hline Central District & 100 respondents \\
\hline Korangi District & 40 respondents \\
\hline East District & 20 respondents \\
\hline South District & 20 respondents \\
\hline Malir District & 10 respondents \\
\hline West District & 10 respondents \\
\hline
\end{tabular}

In this study, quantitative data was analyzed through frequency distribution, however the hypotheses are analyzed through applying the chi-square test of independence with having cross-tabulation; chi-square test table and a bar chart. 


\section{Testing hypothesis}

Testing Hypothesis No. 1: Migrant families desire to live in squatters' settlements.

Ho: Migrant families do not live in squatters' settlements.

H1: Migrants families live in squatters' settlements.

\section{Birth Place * Squatters Settlements Cross Tabulation}

\section{Count}

\begin{tabular}{|c|c|c|c|c|}
\hline & \multirow{2}{*}{ Place } & \multicolumn{2}{|c|}{ Squatters Settlements } & \multirow{2}{*}{ Tota } \\
\hline & & Leased & Not Leased & \\
\hline \multirow[t]{5}{*}{ Birth Place } & \multirow{6}{*}{$\begin{array}{l}\text { Interior Sindh } \\
\text { Punjab } \\
\text { Khyber Pakhtunkhwa } \\
\text { Karachi } \\
\text { Kashmir }\end{array}$} & 30 & 13 & 43 \\
\hline & & 40 & 13 & 53 \\
\hline & & 10 & 8 & 18 \\
\hline & & 44 & 34 & 78 \\
\hline & & 5 & 3 & 8 \\
\hline Total & & 129 & 71 & 200 \\
\hline
\end{tabular}

\section{Chi-Square Tests}

\begin{tabular}{|c|c|c|c|c|c|c|}
\hline Tests & Value & df & $\begin{array}{c}\text { Asymp. } \\
\text { Sig. (2- } \\
\text { sided) }\end{array}$ & $\begin{array}{c}\text { Exact } \\
\text { Sig. (2- } \\
\text { sided) }\end{array}$ & $\begin{array}{c}\text { Exact } \\
\text { Sig. (1- } \\
\text { sided) }\end{array}$ & $\begin{array}{c}\text { Point } \\
\text { Probability }\end{array}$ \\
\hline Person Chi-Square & $6.180^{\mathrm{a}}$ & 4 & .186 & .188 & & \\
\hline Likelihood Ratio & 6.279 & 4 & .179 & .198 & & \\
\hline Fisher's Exact Test & 6.283 & & & .176 & & \\
\hline $\begin{array}{c}\text { Linear-by-Linear } \\
\text { Association }\end{array}$ & $3.854^{\mathrm{b}}$ & 1 & .050 & .056 & .028 & .007 \\
\hline N of Valid Cases & 200 & & & & & \\
\hline
\end{tabular}

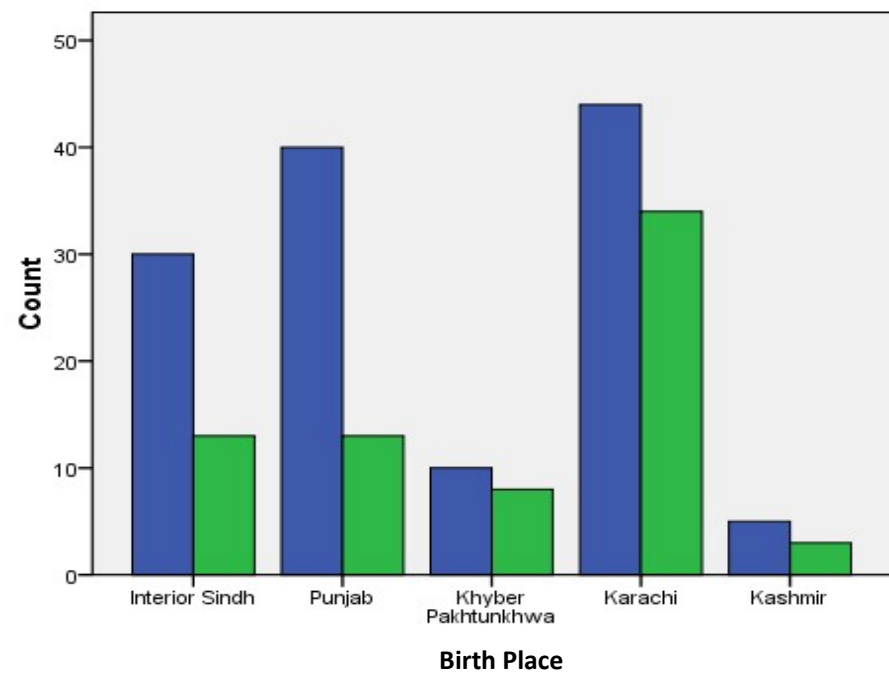

SquattersSettlements

$\square$ Leased

Not leased 
Pearson Chi-Square value is $6.180^{\mathrm{a}}$

The p-value is 0.007

Degree of freedom is 5

It concludes that p-value $0.007<0.05$, which shows clearly that there is strong relationship between two variables 'birth place' and 'squatters settlements'. Hence, Ho is rejected and H1is accepted that migrant families live in squatters' settlements.

This research unveils the causes of migration to Karachi, according to the results about 60 percent of people were migrated due to have better jobs in a way to earn enough money for livelihoods. The commodities and household expenses are increased to unaffordable prices; so, during inflation they used to live hand to mouth situations by the end of month in their villages. Respondents informed that due to extreme poverty squatters planned to migrate in urban areas for better employment opportunities. About 50 percent of respondent in the sample said that they migrated only for the sake of better future prospects of their families. Whereas there is another unusual response receive that people migrated in order to achieve the social liberty. As it can only achieved in civilized societies; where people should have access to justice; free mobility; participation in decision makings without any basis of class; creed; ethnicity and religion. Though it was all there assumptions and after experiencing life in squatters they realize the conditions are not good but quite better as they are affording daily expenses of their families.

Testing Hypothesis No. 2: Families of petty occupations and artisans live in squatters' settlements.

Ho: Families of petty occupation and artisans live in squatters' settlements. H1: Families of petty occupations and artisans do not live in squatters' settlements.

\section{Count}

Petty Occupation* Squatters Settlements Cross Tabulation

\begin{tabular}{|l|l|c|c|c|}
\hline \multicolumn{2}{|l|}{ Occupations } & \multicolumn{2}{c|}{ Squatters Settlements } & \multirow{2}{*}{ Total } \\
\cline { 2 - 4 } \multicolumn{2}{|l|}{ Petty Occupation } & Geased & Not Leased & \\
\hline & Labour Servant, Peon, Driver & 20 & 13 & 33 \\
\hline & $\begin{array}{l}\text { Self-employed in Micro- } \\
\text { small works }\end{array}$ & 23 & 10 & 33 \\
\hline & Service in informal economy & 36 & 8 & 17 \\
\hline & Grocery \& medical store & 41 & 18 & 54 \\
\hline Total & & 129 & 71 & 63 \\
\hline
\end{tabular}




\section{Chi-Square Tests}

\begin{tabular}{|c|c|c|c|c|c|c|}
\hline Tests & Value & df & $\begin{array}{c}\text { Asymp. } \\
\text { Sig. (2- } \\
\text { sided) }\end{array}$ & $\begin{array}{c}\text { Exact } \\
\text { Sig. (2- } \\
\text { sided) }\end{array}$ & $\begin{array}{c}\text { Exact } \\
\text { Sig. (1- } \\
\text { sided) }\end{array}$ & $\begin{array}{c}\text { Point } \\
\text { Probability }\end{array}$ \\
\hline Person Chi-Square & $1.720^{\mathrm{a}}$ & 4 & .787 & .791 & & \\
\hline Likelihood Ratio & 1.690 & 4 & .792 & .800 & & \\
\hline Fisher's Exact Test & 1.780 & & & .784 & & \\
\hline $\begin{array}{c}\text { Linear-by-Linear } \\
\text { Association }\end{array}$ & $.075^{\mathrm{b}}$ & 1 & .784 & .804 & .410 & .038 \\
\hline N of Valid Cases & 200 & & & & & \\
\hline
\end{tabular}

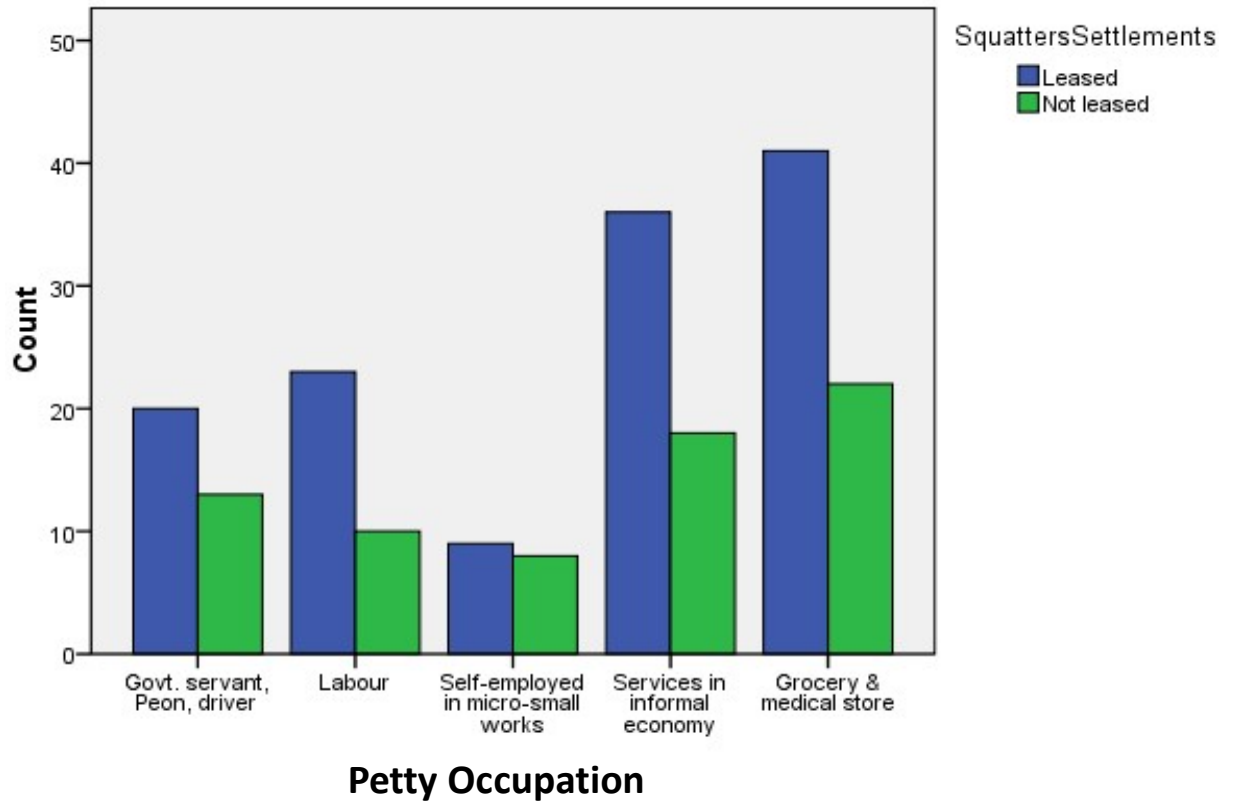

Pearson Chi-Square value is $1.720^{\mathrm{a}}$

The p-value is 0.038

Degree of freedom is 4

It concludes that p-value $0.038<0.05$, which shows clearly that there is no relationship between two variables. Hence, Ho is accepted.

The research is observed multi professions of squatters' settlements. In the survey the most common job among squatters is of labourer about 17.5 percent engaged in this occupation. Because it does not need any expertise to get the job and it is always associated with the physical working. There is another group of around 9.5 percent squatters who are working in grocery stores. The sample includes men and women both during the data collection, due to the reason in occupation section there are 14 percent of women who are performing household work as 
housewives. Whereas, about 5 percent of the respondents are self-employed such as vendors; selling junk food on streets and so on. It is also observed through this research that poor squatters also working as drivers ( 7.5 percent) and peons (7.5 percent) at different places including organizations; institutions and in houses. It found that out of 200 sample there are 2 squatters (1 percent) who are working in government institutions on lower income jobs. Other jobs are included: government servants (1.5 percent); electricians (1 percent); male maids (8 percent); factory workers (3.5 percent); Hair dresser (5 percent); School teacher (3 percent); Ladies clothing (1 percent); Plumber (1.5 percent); Religious teachers (1 percent); medical store (1 percent); sweeper (5 percent); Garbage collector (2.5 percent); waiters in hotels (3.5 percent); and cobbler ( 1 percent). It is observed that there are push factor for squatters in getting employment as they are living in poverty and want employment to earn besides join field of interest. Even governments and policy makers did not make any single plan for employment generation in Karachi so far especially for squatters' living in slums.

\section{Results and Discussion}

Types of family: During the survey it is found that squatters' settlements patterns and structure of livings are not different from people living legally in the society. As squatters are inhabited both type of families including nuclear families and joint families. The sample has mass respondents of about 80.5 percent who are living under nuclear family system. It is witnessed that most commonly a single family migrated from rural to urban cities rather expanded joint families. There are about 19.5 percent of squatters who are living in joint families in the sample. It is investigated that the joint families did not come together; the other members of the family gradually migrated to the city and adjusted in existing households of their relatives. Due to the reason squatters settlements are densely populated as their housing's sprawls on that small piece of land which looks overcrowded in Katchi Abadis' or squatters' settlements. According to the UN-Habitat (2010) estimates urban population will increased by two billion and at the same time rural population will have decline of around 300 million people around the world.

Education of squatters: It is observed during the survey that about 42 percent of respondents are literate (they can read and write) our national language. However, there are 15 percent of squatters are illiterate because they do not attended any institution for getting education. There are people who had attended primary level education in schools, they constituting only 17.5 percent, whereas 12 percent were successful in attaining matriculation, it seems like they can understand the importance of education in their circle and will motivate their children and others for getting higher education. However, there are nominal presence of squatters in Intermediate (6 percent); and Graduation (7.5 percent). According to the UNESCO global monitoring report (2017) around 264 children of under 18 years 
are out of schools and have no access to education. In fact about 75 million illiterate adults are women, which is considered the most deprived gender in the world. The organization emphasizes that it is the best investment for the future peace and make progress and sustainability across the globe.

Monthly income of squatters living in slums: The survey revealed that around 27 percent of squatters' monthly income ranging between 10,000 rupees to 15,000 rupees. However, there is another group of around 26.5 percent whose earnings are less than 10, 000 rupees. The research found group of 25.5 percent squatters', where they have no estimated monthly income. As they work on temporary basis by which they earn small wages. Whereas, there are few who have income more than 20,000 rupees. Even the squatters' group does not have specific working tasks, they may get involved in any kind of work in order to earn for daily food. It is obvious that there are fewer occupation for squatters' to work; and have income in fraction which are not enough to bare the expenses of household. It is further added that UN-Habitat (2015) urged the federal governments of developing nations to make strategic and central policy approach for adequate and affordable housings for all income groups especially in urban context in a way to provide justice among their citizens.

Economic condition of households: The household economic conditions are vulnerable as respondents have received mix responses of squatters between satisfactory and unsatisfactory as facing difficulties in running the family. A significant group of about 47 percent squatters' living satisfactory conditions; giving credit to own selves as they bare all expenses in household by own resources. Squatters have different view about satisfaction levels of household economies as borrowing from relatives; friends and at retailer shops in order to curtail monthly expense of household is under satisfaction level. It shows that squatters believed that curtailing monthly expense of household is satisfying conditions by any means. However it folds the burden on squatters because in low earning they cannot payback borrowed money, besides not able to bear own monthly domestic expenditures. According to the data collection about 92 responded that they are unsatisfactory economic conditions. Here many aspects can be attributed with their unsatisfactory levels. As inflation or higher prices of foods and commodities is one of the challenging issues in Karachi, where it has increased to manifolds for last decades to till now. About 27 percent of respondents said that inflation is the most hindering factor behind unsatisfactory economic condition of squatters. Other group of about 8 percent associating bad condition because of low-income jobs; 6 percent responded that it is due to wages work in informal sector of the economy; and 4 percent said that it is due to increased expenses of households. However, one percent of squatters responded that from their small sum of income, they have to repay borrowed money to the lenders due to the reason economic condition of households is pathetic. Slums 
emerges because of the urban poverty, and the poor's living in such areas will remain poor (International Development, 2013). It has a logic, as good economic conditions are dependent on income, and the income of squatters is fewer as the have been working in the informal sectors so, they cannot built better housing and even cannot afford the rents; due to the reason housing quality is poor and have limited resources.

Construction of house: The research observed that about 43 percent of semi RCC housings of squatters in Katchi Abadis' which are considered quite reliable and pretty amount spend on such type of housing constructions. There is another group of 33.5 percent who are inhabited in reinforced concrete (RCC) house which is considered simple place of accommodation and considered sustainable for long period, made up of concrete. About 14 percent of squatters have shacks as temporary housing for their families. However other group are also living in huts; shanties; and in shacks which are made up of sheets. Such housings are not reliable in times of rain; and in earthquakes due to the reason it is said that squatter's settlements suffer the most in natural disastrous in all over the world. The UN-Habitat (2010) explained that no access to finance is the major cause of poor housing provisions, in fact conventional housings and all other basic necessities are acquired by the higher-income groups of people in developing nations.

Availability of utilities in the household: The survey is again revealing improved figures of water connection in Katchi Abadis. As 79.5 percent squatters' settlements have direct water connection in their dwellings. Total 19.5 percent of squatters have no water connection in their dwellings. The squatters are exploring ways to get water for daily usage for house in such conations about 6 percent of squatters are buying water from tankers; 5 percent squatters managing by themselves to bring water from different places including boring water; from Masjid, fetching water from hand pump; using boring water; filing water from nearer houses and bungalows. As water is basic necessity of every individual; and it should be the responsibility of the government or state to provide water in all the areas on equality basis. Similarly about more than half of sample 62 percent have legal electric connections which were obtained by the K-Electric. However the kunda system in Karachi there is parallel power supply which is called as the Kunda system. Whereas the Kunda expression applied for the connection which are acquired other than legal procedures. But the sample of around 27.5 percent highlighted the legal Kunda system which was observed in squatters' settlements. In such case, they have no proper billing on connections but have fixed monthly amount. Around 4 percent of squatters are using illegal connection of electricity in Karachi and 3 percent of squatters have no electricity in their dwellings. K- 
Electric is working hard to end load shedding and increase production of electricity to meet the demand but these kunda systems are impediments which are sabotaging their efforts. As circular debt increased due to non-payments on use of electricity however, the Kunda system is deteriorated the condition in the megacity. Moreover gas is considered an essential in every household in order to cook food or for other related work. Due to the reason about 90 percent of squatters have sui-gas connections in squatters' settlements. However, only 10 percent have no sui-gas connection in households, in this case they are using other fuels for instance coal, wood and gas cylinder. According to the IEA (2013) about 75 percent of energy especially electricity consume in urban areas but in informal settlements of urban areas, there is a dire need of electricity. It is estimated that around 1.3 billion people have no access to electricity and 2.6 billion have no clean cooking facilities in squatter settlements of the world.

\section{Conclusions}

At present the conditions of squatter settlements are pathetic in Karachi. It is observed that government has taken appropriate measures to stabilize the socioeconomic condition through establishing the SKAA which is working for regularizing Katchi Abadi's but budget allocations in fiscal years are small for development purpose, which are not enough to cater the huge population of squatter settlements in Karachi. In fact the release of funds to the organization is very low which is preventing smooth work for the development of settlements. As per collected data, many of Katchi Abadi's have been regularized and leased by the SKAA. It is also found in the study that about 65 percent of squatters have leased households in the settlements; whereas other respondents informed that officials of SKAA have taken bribery for leasing the settlement and in fact the procedures and documentation for regularization of Katchi Abadi's are tough to meet the requirements due to the reason squatters are reluctant to regularize their squatters.

\section{Recommendations}

This research study has following recommendations:

1. There must be appropriate planning by the economic division for migrating population in a way to meet demands of housing, employment and other utilities. 
2. SKAA's survey team must be strengthen to find out all the existing katchi Abadis' of Karachi and also help to work for better socio-economic conditions of squatters living settlements and slums.

3. The government should allocate budgetary amounts for adequate housings for squatter's settlements in every financial year, as per the need of population.

4. There must be vocational training centers for adult population in Katchi Abadis' of Karachi to make them skilled which will provide secure jobs to them.

5. The government should increase the budget in educational and health sectors in order to provide education and good health to all citizens without any discriminations.

\section{References}

ADB. (2008). Resettlement Planning Document: Sindh Cities Improvement Investment Program, Asian Development Bank, Washington DC, p. 9.

ADB. (2012). Gender and Urban Poverty in South Asia: Proceedings Report of the 2012, ADB Publication, Washington, p.(n).

AHKRC. (2016). Rural to Urban Migration: Connecting Opportunities, Addressing Gaps and Harnessing the Potential of Urbanization, Akhter Hameed Khan Resource Centre, Pakistan, p. 2.

Ahmed, R. (n.d.). Socio-Economic Status of Transferred and Non Transferred Urban Slums: A Case Study from Faisalabad, Preston University, Pakistan, p.(n).

Amrith, S. (2011). Migration and Diaspora in Modern Asia, Cambridge University Press, Mexico, p.159.

Anjum (2011, December 06). Squatters Settlements, Pakistan Today. Retrieved from http:/www.pakistantoday.com.pk on December 28, 2017.

Basu, A. R. (1988). Urban Housing in Third World, Mittal Publication, India, p.21.

Birkmann, J. (2006). Measuring Vulnerability to Natural Hazards: Towards disasters resilient societies, United Nations University Press, Paris, p. 347. 
Buhne, Neil (2016, April 26). Urban Poverty, Daily Dawn. Retrieved from https://www.dawn.com on December 24, 2017

Davis, M. (2006). Planet of Slum, British Library, USA, P.5.

Demonstration, Documentation, Mapping and International Institute for Environmental and Development Publication, New Jersey, p.11.

Denis, Ushakov (2014). Urbanization and Migration as Factors Affecting Global Economic Development, IGI Global, USA, p.117.

Dr Ahmed, N. (2016, October 20). Where the poor live, Dawn. Retrieved from https://www.dawn.com on January 10, 2018 .

Dr Yu, Li (2014). Chinese City and Regional Planning System, Ashgate, USA, P.58.

Durrschmidt, Jorg (2013). Everyday Lives in the Global City: The Delinking of Locale and Milieu, Routledge, US, p.9.

Fisher, Tracy (2012). What's Left of Blackness: Feminism, Transracial Solidarities, and The Politics of Belonging in Britain, Palgrave Macmillan, US, p. 75 .

Ghosh, A. K. (2008). Changing Livelihood pattern of slum dwellers in Delhi: From a squatter settlements to a resettlement colony, Social Change Journal, vol.38:3, pp.444-454

Gukurume, S. (2012). Health and Urban Settlements in Zimbabwe, Lap Lambert Academic Publishing, Zimbabwe, p.5.

Haque, C. (2012). Hazards in a Fickle Environment: Bangladesh, Springer, Canada, p. 261.

Haque, C. E. (2012). Hazards in a Fickle Environment: Bangladesh, Springer, Canada, p.280.

Hasan, A. \& Raza, M. (2012). Karachi: The Land Issues, NED University, Pakistan, p.15. 
http://sindh.gov.pk/dpt/SKAA/devp_works.htm retrieved on January 10, 2018.

IMF. (2006). Ghana: Poverty Reduction Strategy Paper Annual Progress Report, IMF publication, Washington.

Ismail, A. (2004). The Story of SKAA: Sindh Katchi Abadi Authority, City Press, Sindh, p.69.

International Development (2013). The Political Economy of Slums: Theory and Evidence from Sub-Saharan Africa, Development Studies Center, London, p.7.

IEA. (2013). Sustainable Energy for all, International Energy Agency (IEA) Publication, World Bank, p.289.

Jansson, B. (2007). Becoming an Effective Policy Advocate: From Policy Practice to Social Justice, Cengage Learning, USA, p.167.

Maheshwari, B., Purohit, R., Malano, H., Singh, V. \& Amerasinghe, P. (Ed). (2014). The security of water, food, energy, and liveability of cities: Challenges and opportunities Peri-urban futures, Springer, Australia, p.166.

Maqsood, Fawad (2016, June 13). Shoaib regretted for not allocating funds for Katchi Abadi in Sindh Budget, Business Recorder. Retrieved from https://www.brecorder.com on February 21, 2018.

McGee, T., Koppel, B. and Ginsburg, N. (1991). The Extended Metropolis: Settlement Transition is Asia, Hawaii University Press, Honolulu, p.71.

National Research Council (2012). Himalaya Glaciers: Climate Change, Water Resources, and Water Security, The National Academy Press, Washington, p.84.

Nenova, Tatiana (2010). Expanding Housing Finance to the Underserved in South Asia: Market Review, The World Bank, Washington, P.11.

Ooi, G. L. \& Phua, K. H. (2007). Urbanization and Slum Formation, National Institute of Education, Singapore, p.(n). 
Perlman, J. (2010). Favela: Four Decades of Living on the Edge in Rio de Janeiro, Oxford University Press, New York, p.46.

Pervaiz, A., Rahman, P. \& Hasan, A. (2008). Lessons From Karachi: The Role of Publication, Washington DC, p. 168.

Rapoport, Amos (2016). Human Aspects of Urban Form: Towards a ManEnvironment Approach to Urban, Pergamon Press, New York, p.100.

Ruskulis, O. E. \& Schilderman, T. (2005). Building Bridges with the Grass Roots: Scaling-up Through Knowledge Sharing, ITDG Publishing, p.4.

Sanchez-Triana, E., Afzal, J., Biller, D. \& Malik, S. (2013). Greening Growth in Pakistan through Transport Sector Reforms: A Strategy Environment, Poverty, and Social Assessment, The World Bank Publication, Washington DC, p.65.

Satterthwaite, D. \& Hardoy, J. (2014). Squatters Citizen: Life in the Urban Third World, Routledge, New York, p.(n).

Seto, K., Solecki, W. \& Griffith, C. (Ed). (2016). The Routledge Handbook of Urbanization and Global Environment Change, Routledge, New York, p.53.

Tariq, Hussain (2017, September 3). About the Census 2017, Pakistan Today. Retrieved from https://www.pakistantoday.com.pk on January 24, 2018.

The Express Tribune (2017). Five Big KatchiAbadis' Regularized in Karachi, The express Tribune. Retrieved from https://www.tribune.com.pk, on December 28, 2017.

The Guardian (2012, December 03). Squatters criminalized not stealers, The Guardian, England. Retrieved from https://www.theguardian.com on December 9, 2017.

Thompson, J. (2002). Drawers of Water II: 30 years of change in domestic water use and environmental health in east Africa, IIED, USA, p.3. 
Umar, B. and Indo, B. (2017). Urbanization and Its Impact on Socio-Economic Growth in Developing Regions, IGI Global, USA, P.131.

UNDP. (2002). Local Initiative Facility for Urban Environment: Katchi Abadis and Some Viable Alternates, United Nations Development Program Publication, Islamabad, p.10.

UNESCO (2010). Desalination and Water Resources: Water Health-Volume II, Eolss Publisher, United Kingdom, p.259.

UN-Habitat (2000). Regional High Level Meeting in Preparation For Istanbul+5 for Asia and The Pacific, UN-Habitat Publication, China, P.99.

UN-Habitat (2016). Slum Amanac 2015/2016: Tracking Improvements in the Lives of Slum Dwellers, UN Habitat Publication, Nairobi, p.12.

United Nations (2005). Urban Environment Governance for Sustainable Development in Asia and the Pacific: A Regional Overview, UN Publication, Washington DC, p.72.

United Nations (2010). Bridging the Urban Divide, UN Habitat Publication, Washington DC, p.39.

United Nations (2014). World Urbanization Prospects, UN, New York, p.2.

United Nations (2014, July 10). World's Population increasingly urban with more than half living in urban areas, UN publication, New York, p. (n).

United Nations Educational, Scientific and Cultural Organization (2012). Institute for Statistics. UNESCO Publication, Geneva, p.(n).

UN-Habitat (2010). Chapter 1: Development Context and the Millennium Agenda: The Challenges of Slums: Global Report on Human Settlements 2003, UN-Habitat Publication.

UN-Habitat (2015). Habitat III Issue Papers: Informal Settlements, UN-Habitat Publication, New York, p.7. 
United Nations (2017). Inclusive, equitable and quality education at the heart. Retrieved from: https://www.un.org/development/desa/en/news/ sustainable/high-level-event-education.html on July 18, 2018.

Ushakov, Denis (2015). Urbanization and Migration as Factors Affecting Global Economic Development, IGI Global, USA, P.139

Ushakov, Denis (2015). Urbanization and Migration as Factors Affecting Global Economic Development, IGI Global, USA, P.218.

Wehrmann, B. (2008). Land Conflicts a practical guide to dealing with land disputes, GTZ, Germany, p.23.

Wood, D. (2010). Economic Action in Theory and Practice: Anthropology Investigation, Emerald, UK, P.23.

Yumin, Y. \& Le Gates, R. (2013). Coordinating Urban and Rural Development in China, Edward Elgar, USA, P.38.

Yusuf, H. (2005). Living on the Edge, The herald, Pakistan, p.4.

Aamir Waheed Khawaja is Ph.D Scholar in the Department of Social Work, University of Karachi.

Dr. Nasreen Aslam Shah is Meritorious Professor in the Department of Social Work and Director, Centre of Excellence for Women's Studies, University of Karachi. 